\title{
从黄士線說明黃河河道的發育
}

張 伯 声

(阮北大学地質系)

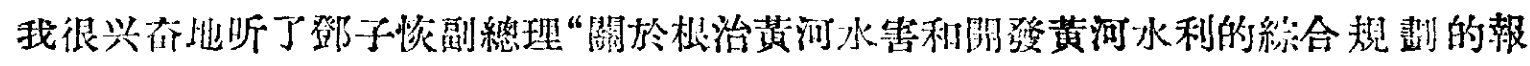

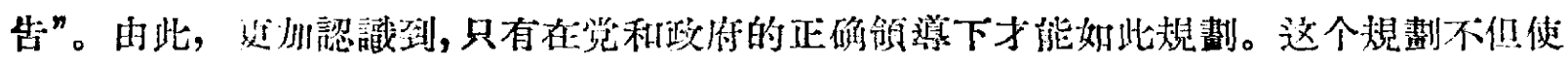

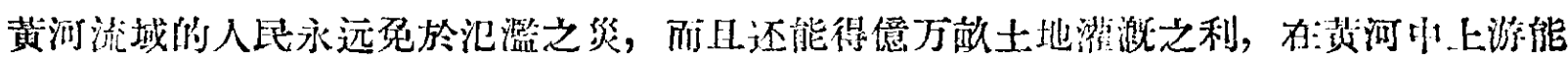

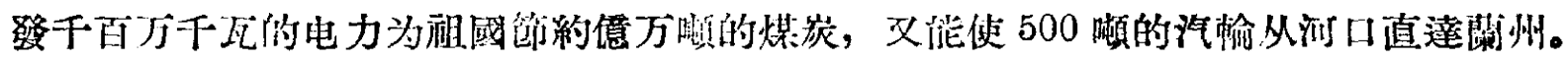
这一远景在不久将來就要实現了，能不合人欢欣鼓僯! 因此回想我过去在黃河及其支流

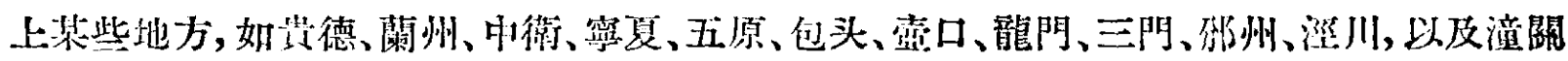
附近的中条山等地的印象, 窵出这篇文章, 以供關心黄河開題的闹志們参考。

\section{一 从黄土線談起}

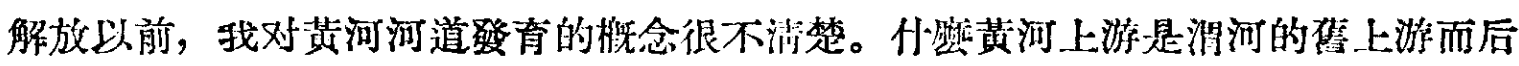

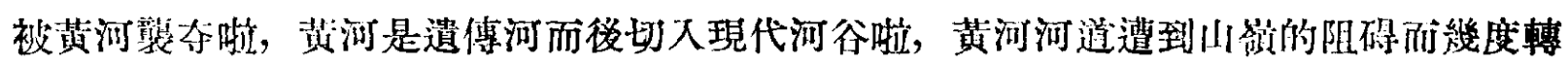

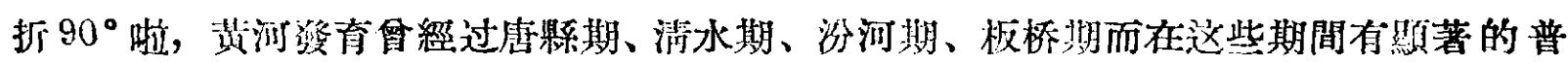

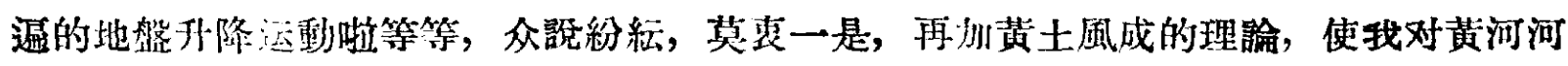
道發育的躴念更为鼬乱。

船独以後，山於到邠州和运城中条山謂 查，设現 $j$ 一些黃士開題，怀疑了黃土風成

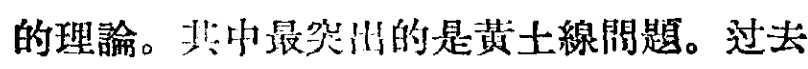
因约於蕉證，認为黄土是存在於山頂、山

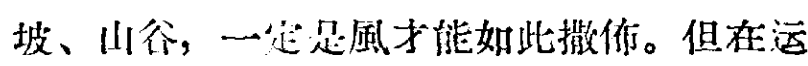
城附近的中条川上發現山北山南雨坡的黃士

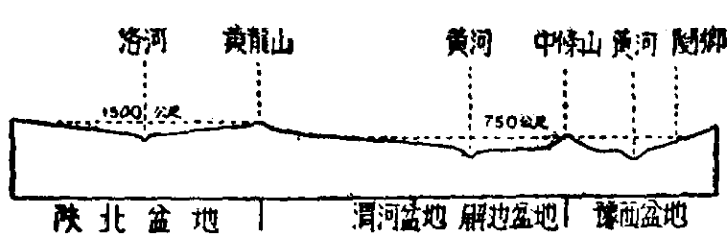

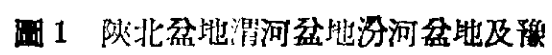

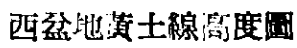

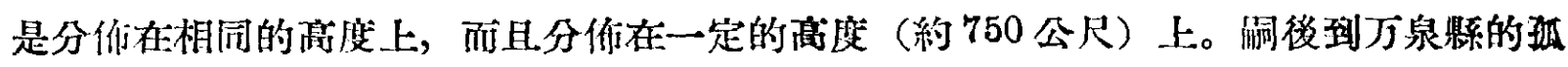
山韭远望积以，又發現黄土所在的最高拔海为 750 公尺左石。从潼關歸來時,特別注意 了中条川南坡及潼關以南的最高黄土原，远望比较，语低相似。从圈鄉到灵宝一段的火 車上远望中条川南坡，黃土分们的最官限幾乎成一条平線，因此得到黄土線这一概念。

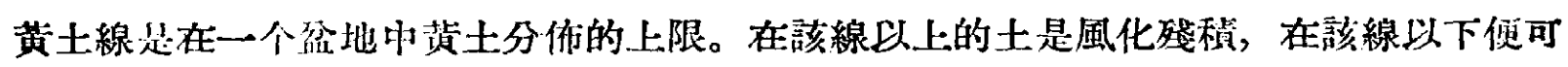
發現顆粒相当均与的黄土。近川处，在黃土底部混淆着砂磷透鏡層。离山越远，这种透 鏡層越少，以至沒有。靠近万泉的坬山和中条山南麓，都有这种情形。 


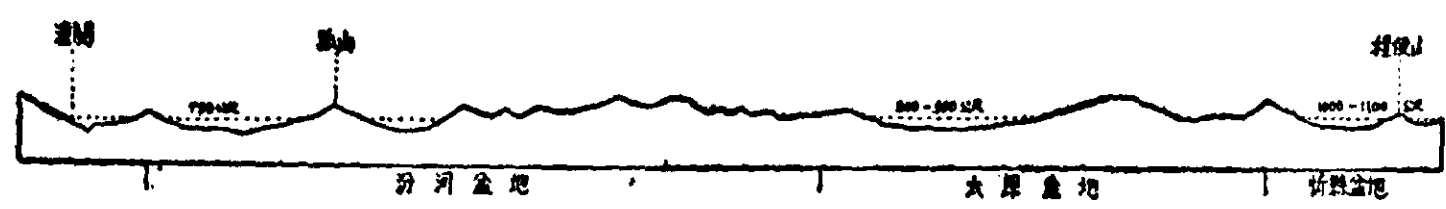

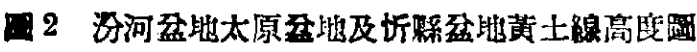

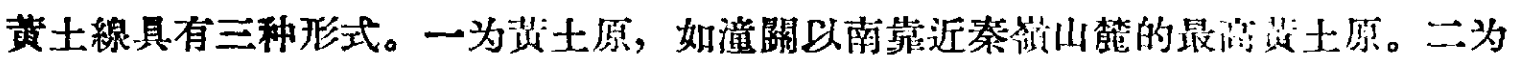

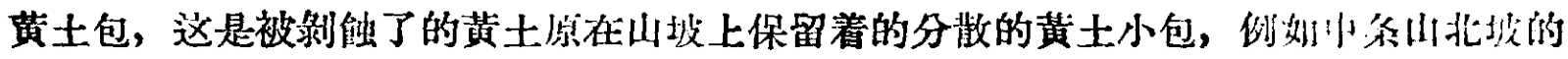

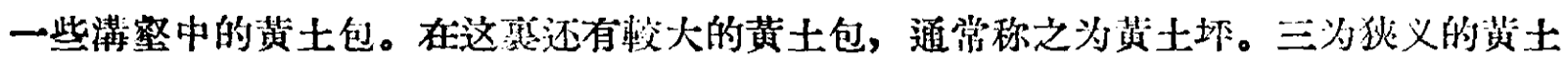

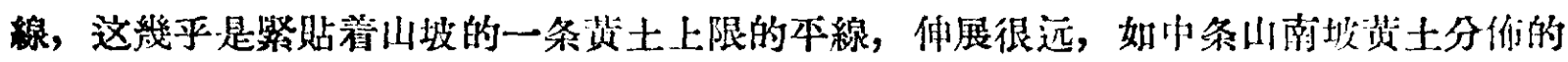

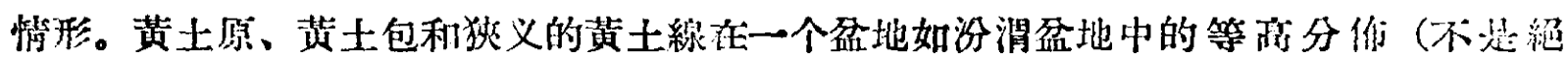

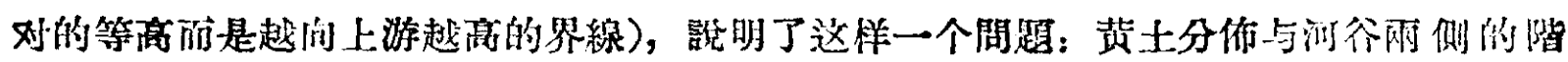

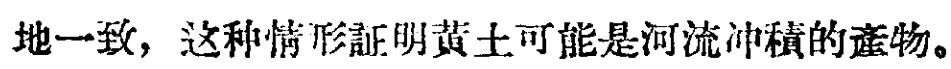

栍据以上的观繁和推測，我回憶从前所 到过的地方，在感孫双十泼（成夥微䅫盈地 的一部分) 的兴士線间利 1,500 公尺，沿 东 河上溯，越到上游，黄土線越畆，形成了河

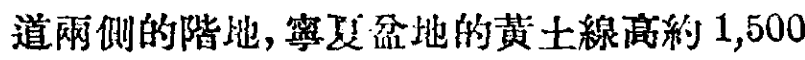
公尺, 籣州盈地的黄土線高約 2,500 公尺。

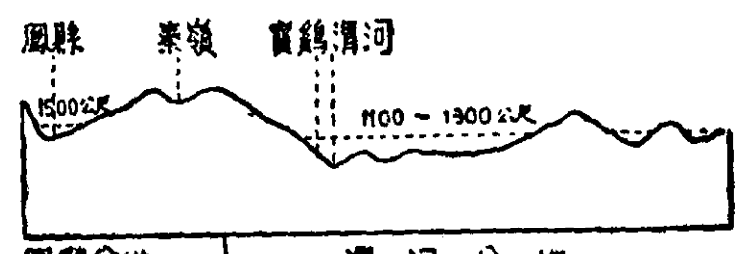

政然盆地

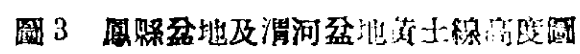

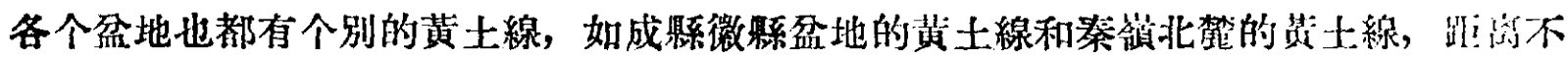

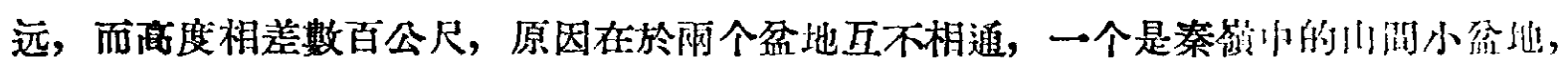

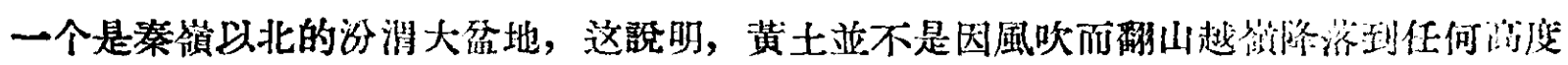

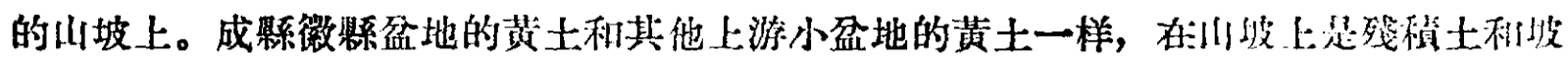
啨土，在山谷中是淤皘土，都是当地们物。从殘皘土、坡積士倒计皘士，粒度越來越

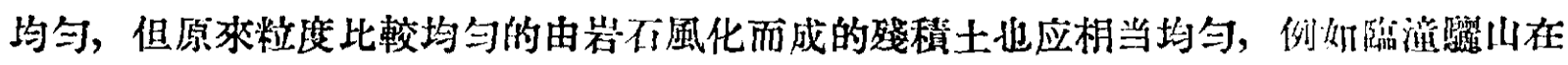

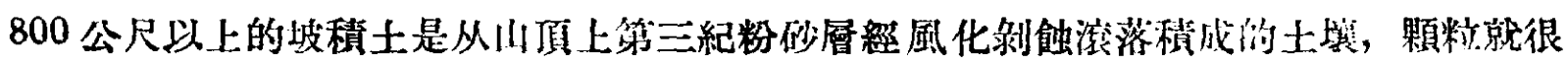

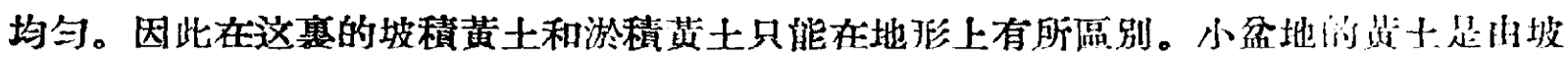

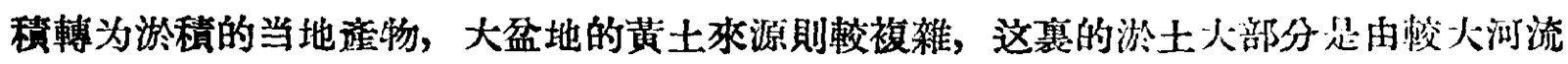
的上游盈地中冲下來的，而上游盈地的淤土則是从更上游的許多小盆地计下來的。

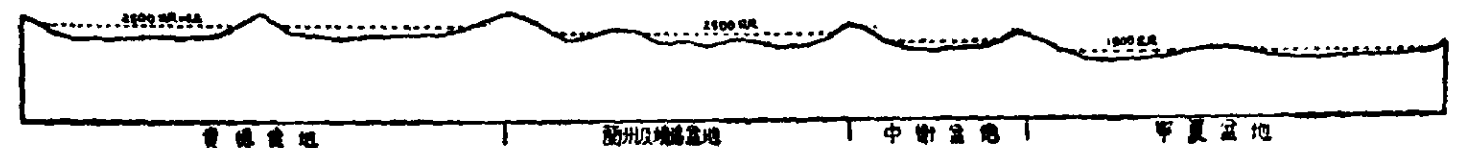

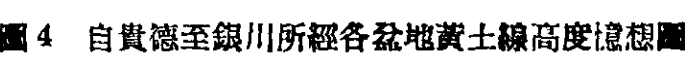

过乾箖，到永寿，黃土線發生了問題，乾䅫是在 750 公尺的黃土原上，与秦虹北坡

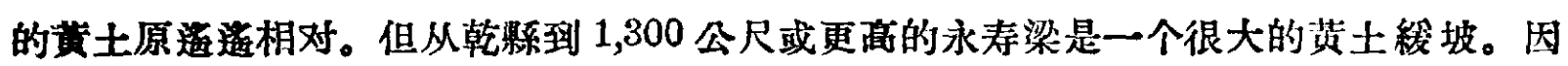
此就生了“汾渭盈地北沿的黄土線到那裏去了?”的間題。

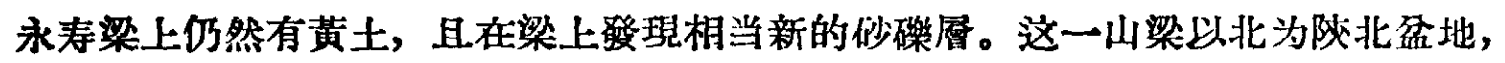

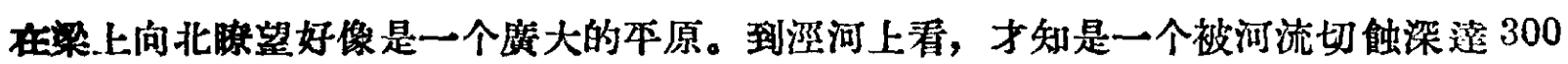
公尺左右的黄土平原, 僅在谷底露出一些基岩和紅層。在涇河雨側上边原來的平原已因流 


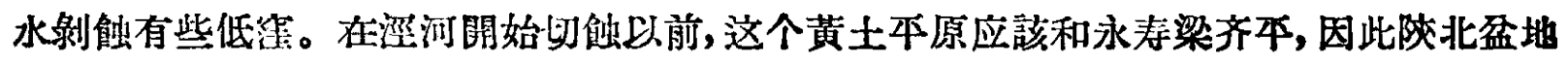
是另一黃土盈地。这裹黄土厚度超过 200 公尺。黄土的漫漼或是从汼多舊河道上冲下來, 或是由於土流滾落, 这种冲下或济落造成了永寿的黃土大坡。因此乾䅫的黄土原与永寿的 黄土坡可說是雨件事，不能相提並論，而渭北黄土線的問題也可以得到解决。

以上所說也可在郃陽韓城得到証明. 邻陽偉城的大部分地區都在 700 公尺以上的黄 土原上。这个黄土原非常顯著。它可以和东附的中条山及南面秦領的黄土原看齐。由韓

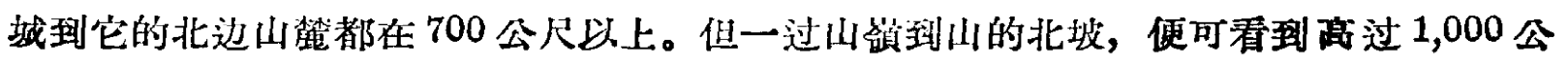
尺的切蝕破䂭的黄士原。从韓城到宜川的路上也可以看到这一點。因此, 北盈地的黄 土線和汾渭盈地的蓝土線量很分明的。

根据中國地筫圖中的黄土露头，参照中國的地形圖，可以在山西境內大致对照这兩

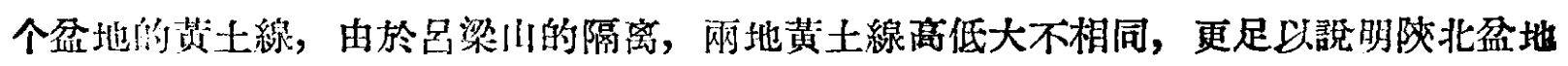
与沙溫盈地的少士地形的發展基本上是不同的。

把中國地質圖与中國地形圖对照一下，又可發現汾渭盈地与華北平原的黄土線地是 截然不阔的。在洛陽东北的印山是黄土粠成的黄河与洛河的分水嶺, 这是一个被剝蚛了 的黄土原的殘留部分, 它的高度在 250 公尺左右。从汇水到京漢路黃河鉄桥沿黄河一帶 有黃土誾, 高应在 200 公尺左右。沿太行山东楚, 黄土的上限則在 200 公尺左右。这个

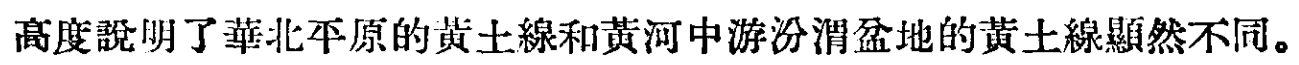

从地圖上可以看出, 汾河盈地的东北䋈接太原盈地, 太原盈地的北端䋈接析夥盈地, 三个盈地有三种不等高的黃土線。汾渭盈地黄土上限約为 700-750 公尺, 太原盆地的黄 土上限約为 900 公尺, 而忻綦盈地的黃土上限約为 1,100 公尺。忻縣北的程侯川四周恰 好多有崩土汕露, 高度也在 1,100 公尺左右, 与盈地四周的黄土線看齐。以上仍然說明,

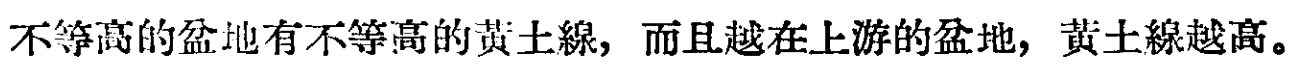

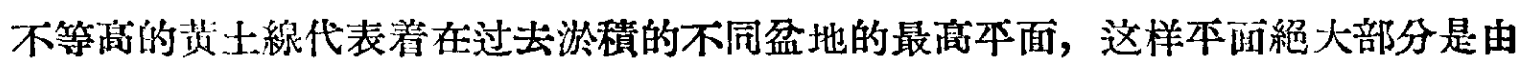
於無數澌洪水漫灘散在一个盈比各处的淤積所造成的。因此, 这一平面不是真正的本面,

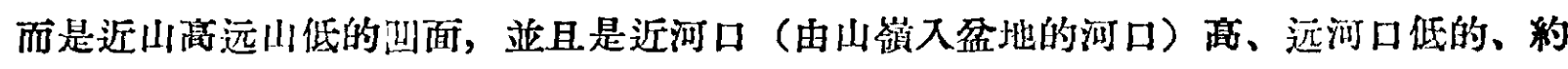
略成起伏狀的边緣。洪水造成的淤積必然是湮没時間很短, 暴露時期很長。特別長期的 暴露是从淤土轉变为黄土的必要条件。

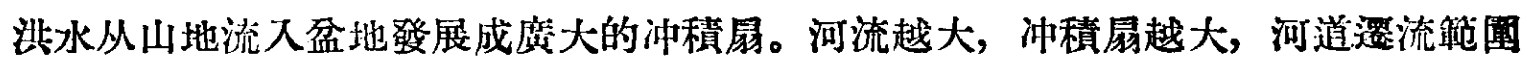
越廣, 因为要流線故, 暴露的時期也就越長。䋔百十年的長期暴露後, 或早或晚地又淤 皘起來, 淤積以啳刃發生变化。生成的開始總是淤土, 改变的結果終成黃士。兴土的剖 面往往夾有或大或小的透鏡狀仯磞層, 有時夾有州狀成層的秥土, 这可以誰都是河道的

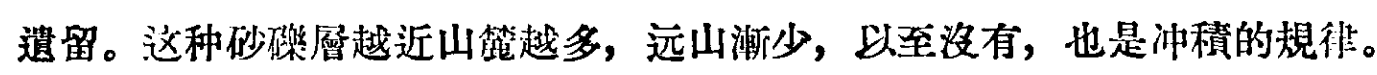

鱼土線既代表古代然數期的洪水漫灘在盈地上的綜合潍皘面, 則它的高度就必須一与 这一盈地在黄土線發展到这一核度的当時最低山口相似。因为当時的淤土虽在盈地出口 处開始流失，但盈地上游还有很多河川繼續進行淤皘，因而上游的黄土線仍在繼縝增高。 所以一个盈地的革土線在下游要低些, 在上游要高些。但高到怎样程度, 則决定於众多 河流的切蝕, 因为盈地出口的加深和向源侵触到上游山笓呫, 黃土線便被破坏。盈地越

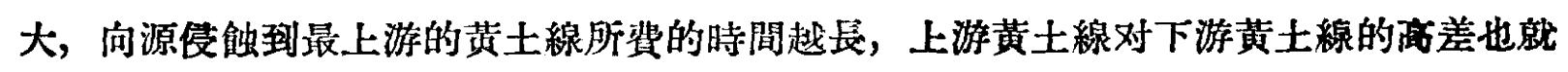

3 月号

科学通 报

- 7 • 
越大。打盈地的西北要比东南的黃土線高得多, 汾河盈地的黄土線在潼關要比宝鵴低 得多, 这就是很好的例子。一个盈地的黄土線还有局部的高羔, 这是在丽条大河之間的

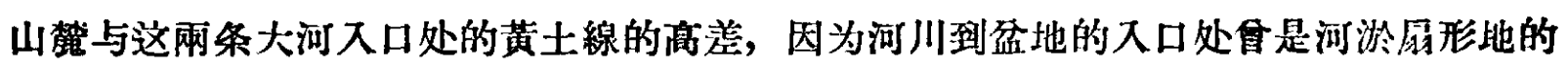

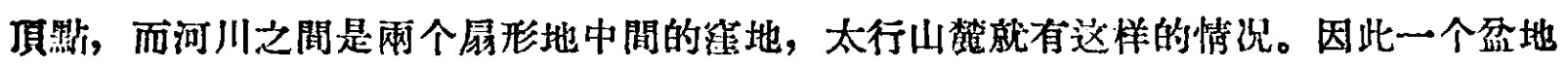
中的莡土線不完全等的，也是很自然的。

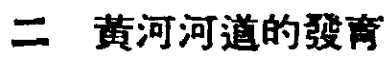

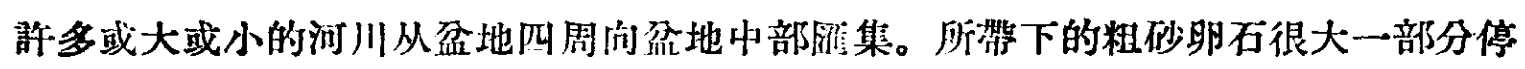

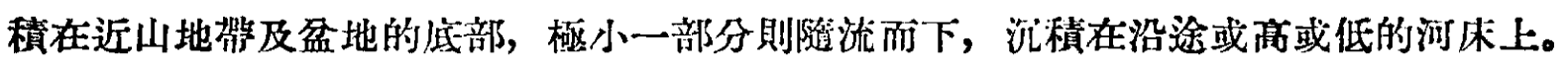

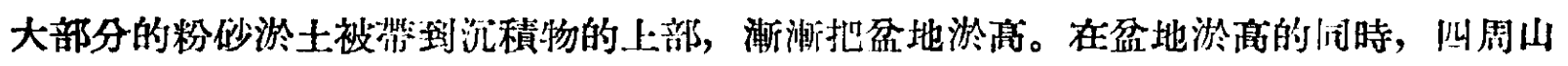

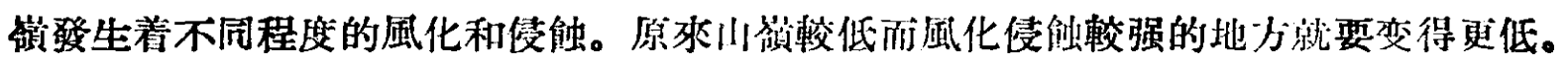

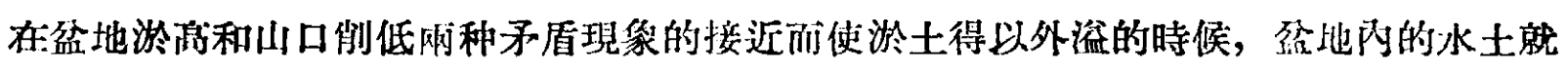

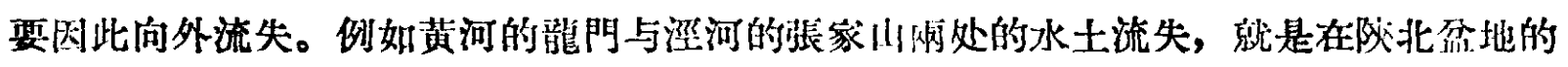

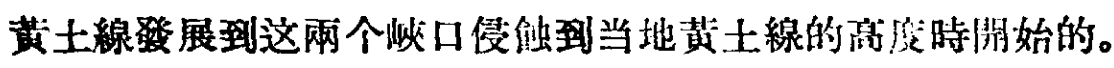

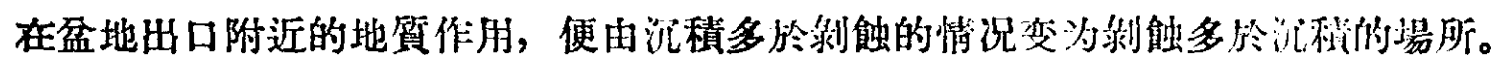

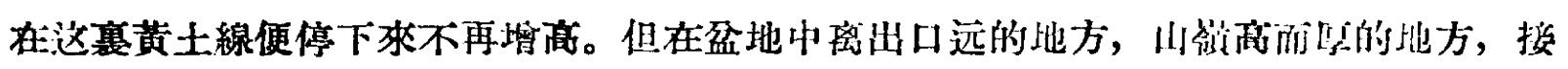

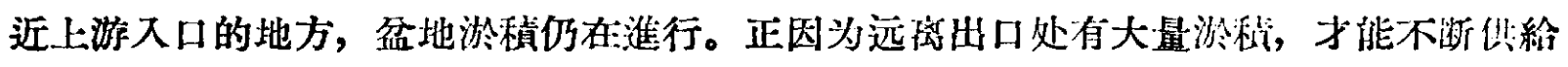
出口处的流先。才使这一盈地的出口以外一—正是下游盈地接受外水沉皘物的入口部

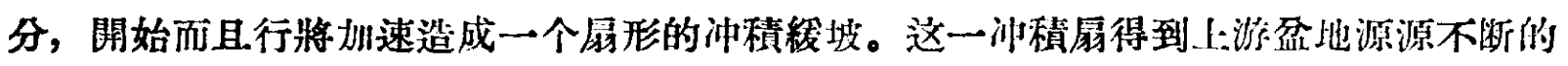

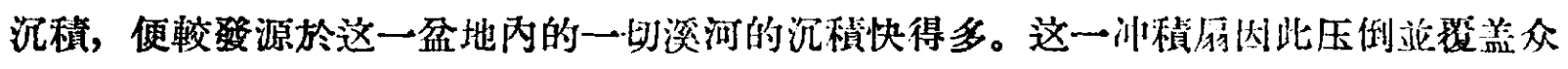

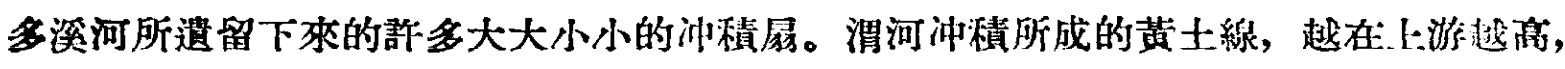

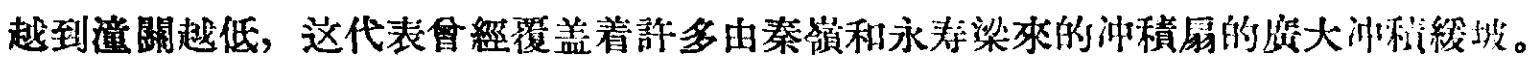

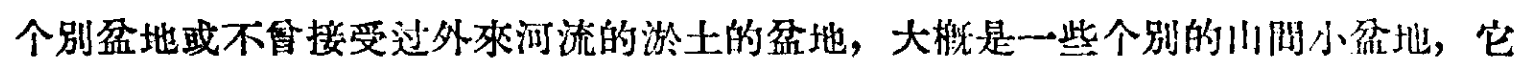

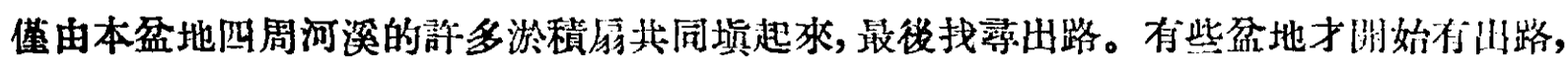

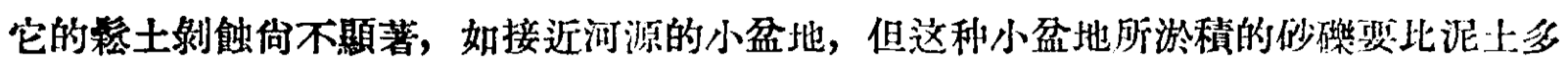

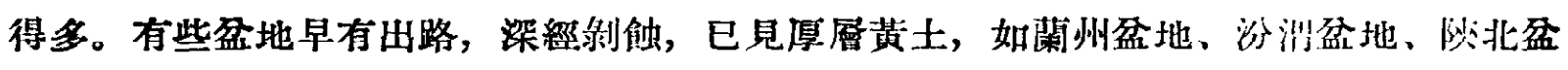
地等都是中流的大盈地, 盈地越大, 接受泥土淤皘越多, 这是由於外将核皘的線故。

个別盈地一經接受外來的淤積以後, 便要㺫速淤積, 找非出路, 因闹成为过路的淤

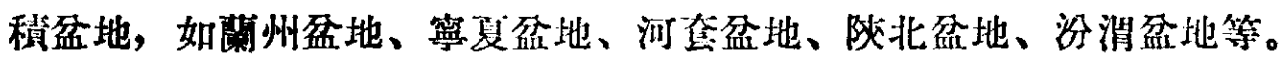

盆地大、出路所在的山嶺厚，虽已有冲触成很長的山惔出路，但还沒有切蚛得很深，

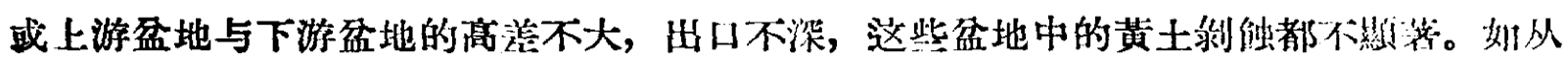

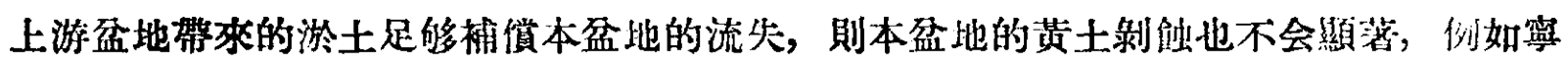
夏盆地和河套盈地。

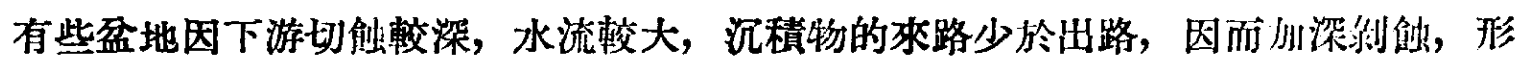

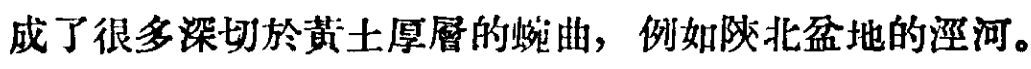

有些盈地因下游出口啺通, 沉皘物的來路远不能榑償本盈地黄土的流失, 則本盆地 的黄土剝触更加顯著, 造成黄土瑇谷、黄士原、黄土包及狹义的黄土線, 例如汾埧盈地。 以上所說悄况，都能在黄河上或其支流上看到。具正沟有出路而正在洪淤的盈地可 
在黄河上游地區看到，例如青海盈地。青游游面拔海 3,040 公尺，从这毫到黃河中間的 坳口为 3,340 公尺。由於山咖剝蝕, 淤皘不到 300 公尺的高度, 便有水土流失。

華北本原僅在西边山楚保留着很低的黄土線或黄士包。

由於以上列举的例子, 可以得到如下的絬論。黃河还沒有形成目前河道的時候, 在 西北就有很多大大小小的盈地。在这些盈地四周進行着風化䟝玲, 在盈地內部則有很多

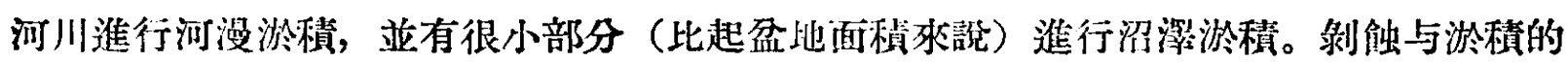

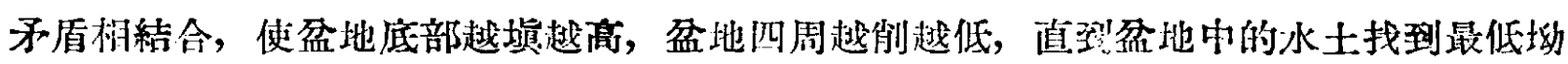

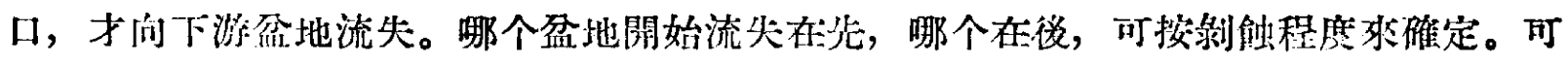
能有些吩地闹時打開缺口，它們的水分別流球不同的盈地。一般來䜅，上游盈地先行淤

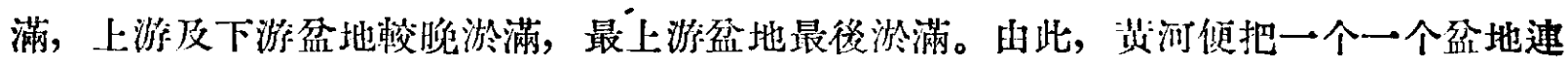

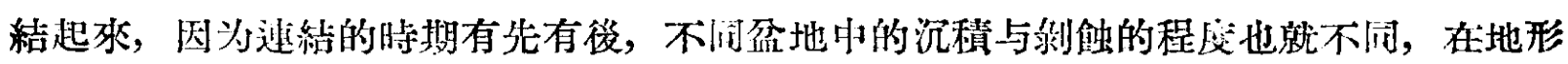

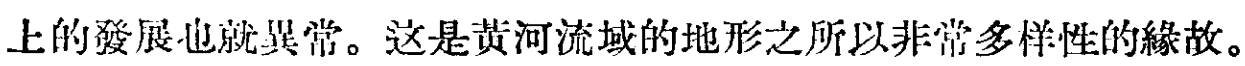

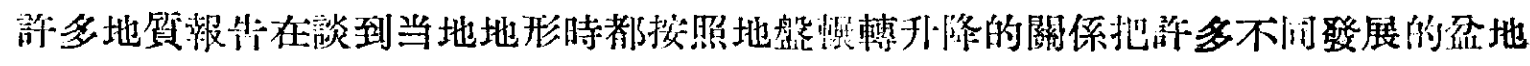

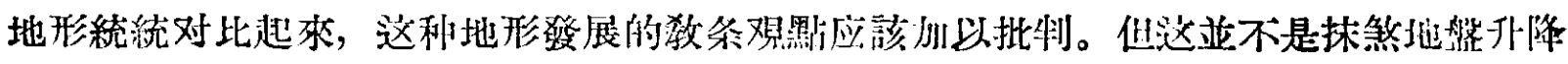

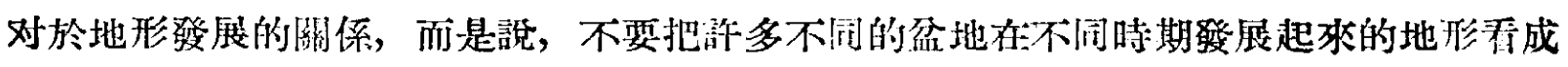

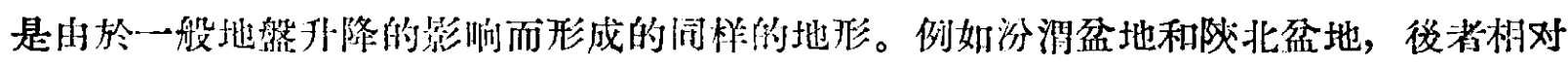
下隆，前都相对上升，爾个盈地的地形發展便不能等量齐覌。虽然它們都有一些類似的 階地, 但也不应亘作比校。

\section{三 黄土原的形成}

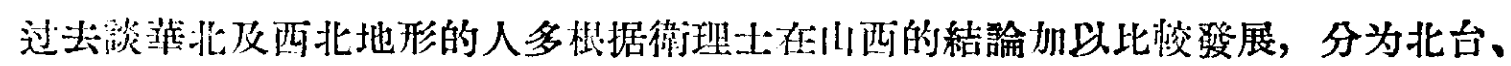

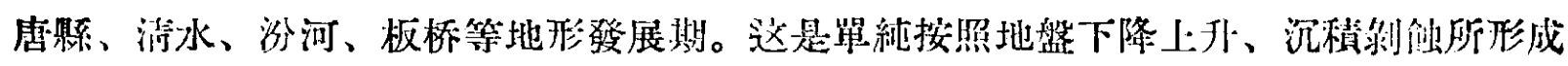

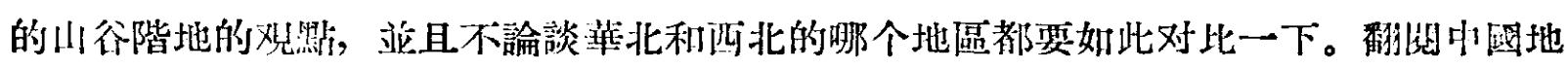
質学会会誌、地質諭䚯，以及其他地質刊物，都可發現这利对比。階地發展自然是地盤

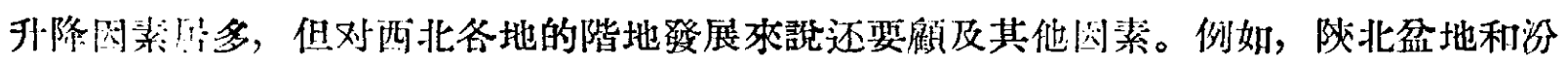

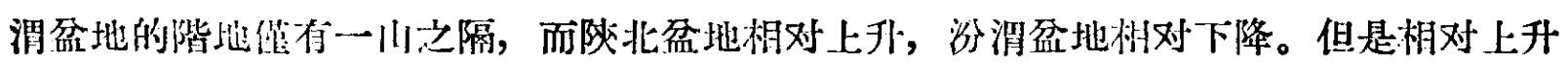

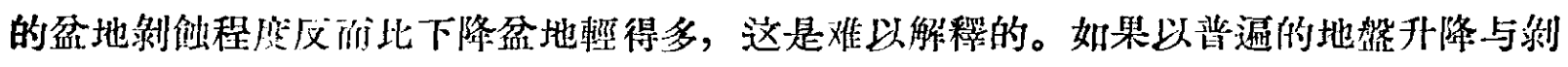

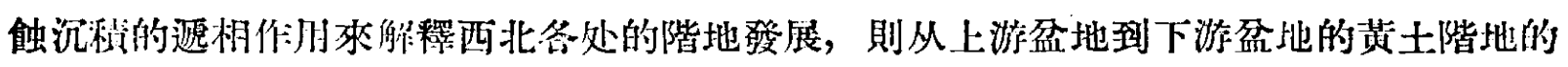

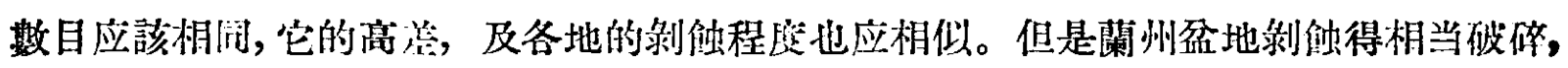

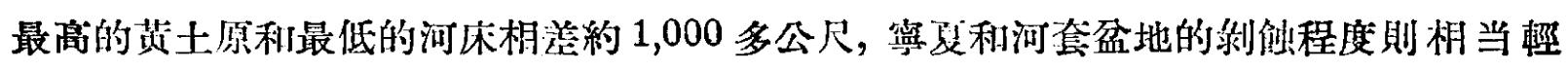

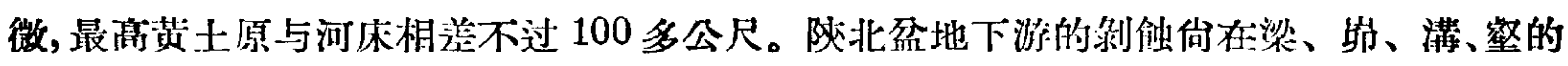

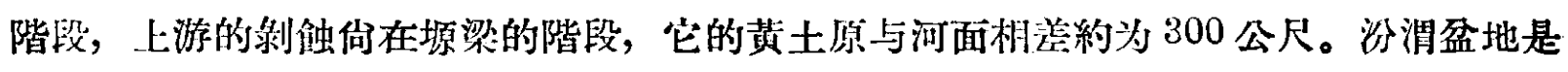
下降地區, 但剝蝕相当强烈, 它的最低黃土原已成度谷平原, 与最湢黄土原相差 300 多 公尺。这就明㙷地詿明了各个盈地的剝蝕与沉程情况大不相同。因此, 我們不能把一个 盈地的黄土原和另一盈地的類似同級的黄土原看作同時期的座物, 也不能把許多盈地中 的許多階地作网样的比较。

如果不把地盤升降看作是西北各地黃土原造成的主要因素, 那末它的主要因素是什 麼呢? 我們可以把盈地出口的地質檢查一下。龍阴是陝北盈地的出口, 生夥以下的山温

\section{3 月号}

科学琚报 


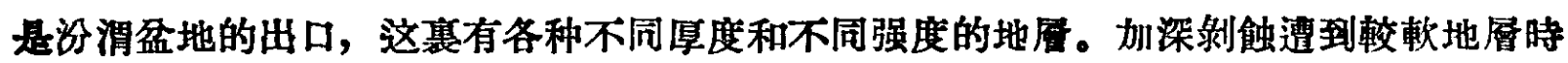
便很快切通，遇到較硬地層便遭受相当長期的阻滞。当出口不能很快被切穿時，上游盈 地中的河流便潜留在某一本面上, 加强了側蝕作用, 因而造成一个度大的冲皘平原。切 穿坚硬地層到達較軟的地啳時, 便加速西蝕作用, 上游盈地也就加深剝強, 把剛成的冲 積平原割切成为階地。如此輾轉下去, 这一盈地便生成幾層階地。

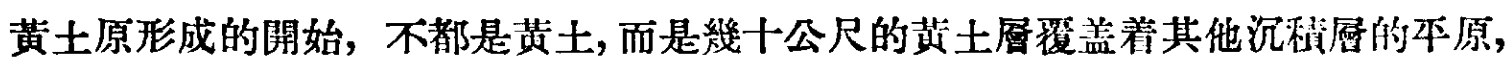

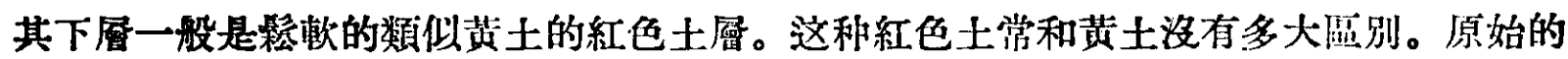
黃土平原在後期的剝蚛中形成黄土原。在这种黄土原与下一級黃土本原接触处，原为淤

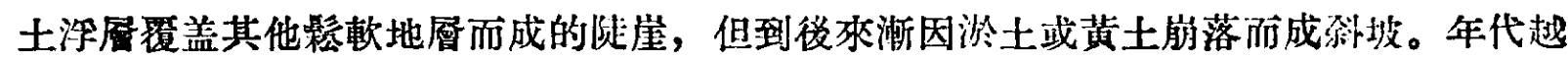

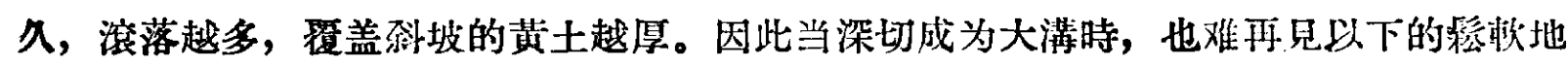
屏。所以在河道雨㑡到处可以看到黃土形成的階地。

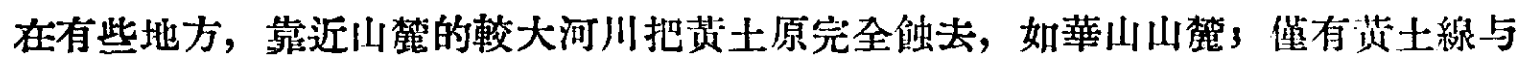

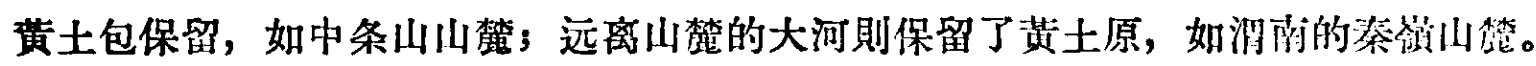

这些黄土原、黄土線、黄士包的發展既然是在淤滿一个盈地找到自己出路以後, 由 於出口处坚軟地層的控制而形成的，則根据黄士原的大小，黄士線或分散的黄士包，就

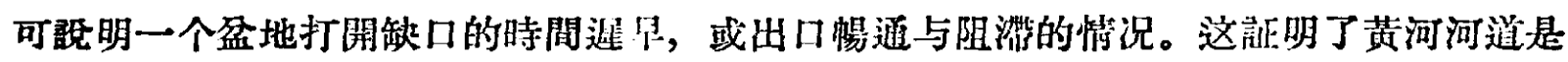
在不同時期內輾轉淤積成或大或小的盈地。

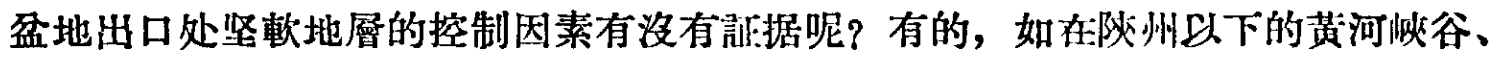

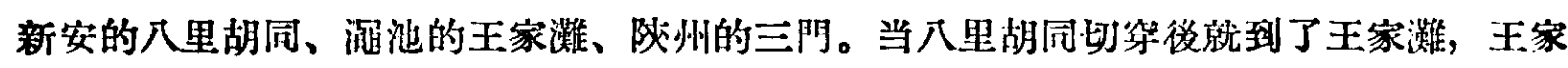

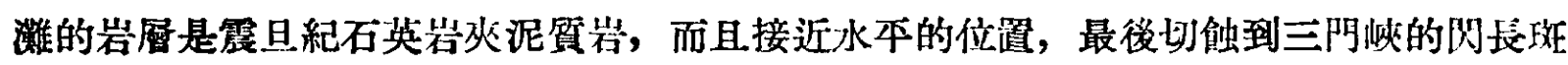

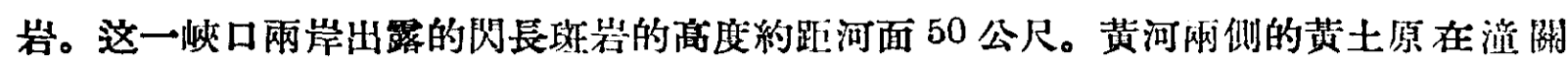

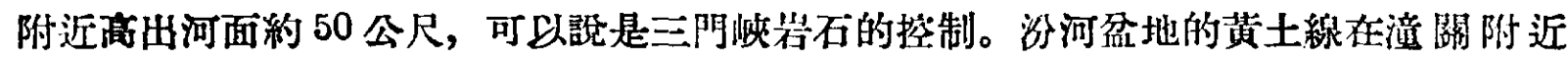
拔海約为 700-750 公尺与王家灌和八里胡同兩岸高度約为 700一750 公尺相符合。其

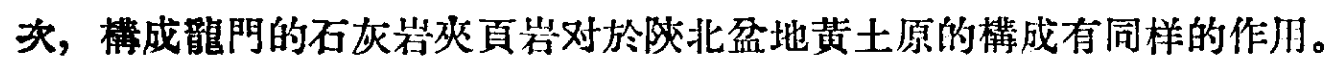

總之，以上所說前不是完全抹繁地盤升降作用对黄河河谷階地發展的關係，但在黃 河所贯穿的各盈地中的階地發展，似乎是盈地出口处坚軟岩層控制因素的影响这大些。

\section{四 結束語}

由於以上論証, 可知黃土的分佈证不是漫山遍野散处於任何高度的, 而是分佈在一

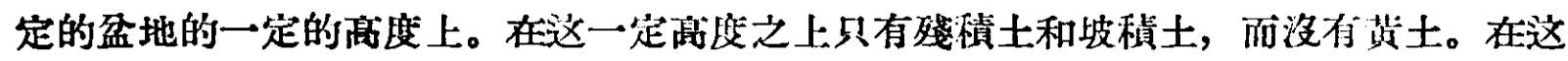

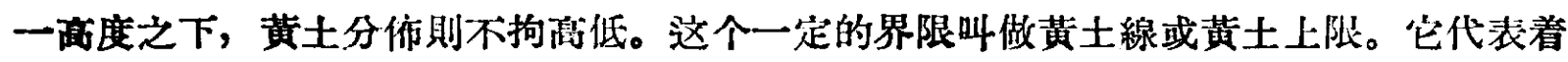
这一盈地在过去河漫淤積的最高地面。

黄河流域大大小小的盈地內部，由於河漫淤皘結合盈地边緣剝蝕，到最低泀口，然 後对本盈地淮行加深剝蝕。由於出口坚顿岩層的控制形成了本盆地的河谷階地。在上游 盈地剝蝕的同時, 鄰近的下游盈地加速河漫淤積, 淤滿以後又同样地向更下游盈地順流 發展。但在上游則是湖源發展, 它的目的是从上游加長黄河。

以上所提關於黄土線、黃河發有及黃河河谷階地形成的假設，只是初步的意見，不 免存在着許多問題，希望同志們予以批評指正。 